\title{
Remembering Stephen T. Warren, a pillar of neurogenetics (1953-2021)
}

S: tephen T. Warren, the founding Chair of the Department of Human Genetics, Charles Howard Chandler Endowed Chair of Human Genetics, and William Patterson Timmie Professor of Human Genetics at Emory University School of Medicine, passed away on 6 June 2021, at the age of 67 . Steve will be remembered for his seminal contributions to neurogenetics, particularly the molecular basis of fragile $\mathrm{X}$ syndrome. Friends, family, colleagues, and trainees mourn his passing, but also celebrate his life and extraordinary achievements.

Born in East Detroit on 30 November 1953, Steve developed a strong interest in human genetics when he was an undergraduate student at Michigan State University. While a first-year student, he began his involvement in medical genetics by volunteering in the clinical genetics diagnostic laboratory, where he continued to work throughout his undergraduate studies and first met his wife, Karen. He spent summers at Henry Ford Hospital in Detroit, learning clinical genetics while seeing patients. Steve continued his graduate studies at Michigan State University, completing his Ph.D. in Human Genetics in 1981. He completed his post-graduate training in the laboratory of Richard Davidson at the University of Illinois in Chicago and European Molecular Biology Laboratory Heidelberg. Steve joined the Emory University School of Medicine as an assistant professor in 1985 in the Departments of Biochemistry and Pediatrics (medical genetics); he was promoted to associate professor in 1991 and then quickly to full professor in 1993. He was an Investigator with the Howard Hughes Medical Institute from 1991 until 2002, when he resigned to establish the Department of Human Genetics at Emory.

Throughout his career, Steve's primary focus has been the elucidation of the molecular basis of fragile X syndrome (FXS), a common inherited cause of intellectual disability and autism, as well as fragile $\mathrm{X}$-associated disorders that result in ovarian insufficiency and late-onset neurodegeneration. Steve was first introduced to fragile $\mathrm{X}$ syndrome during his postdoctoral training when he started developing the strategy to clone the fragile site. Exactly 30 years ago, his

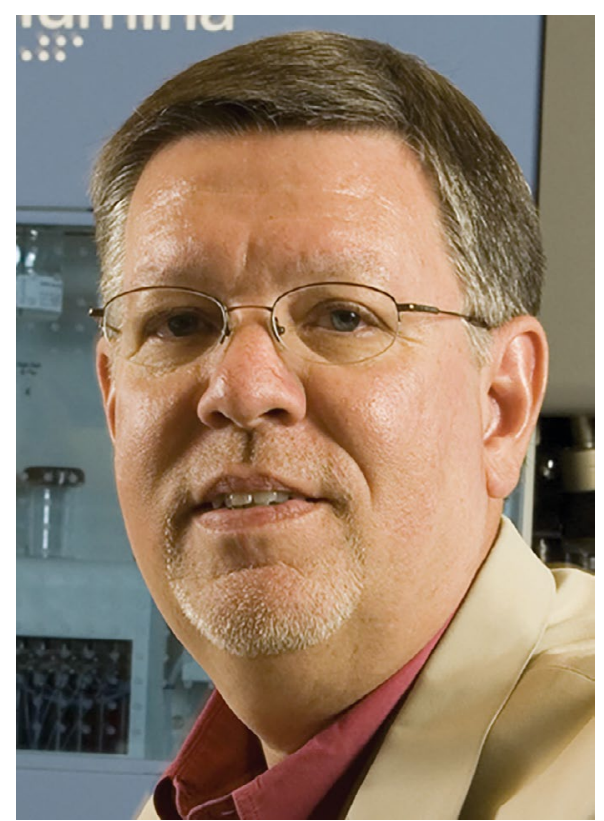

Credit: Karen Warren

collaborative work with David Nelson, C. Thomas Caskey, and Ben Oostra led to the discovery of the causal gene, FMR1. The identification of the CGG repeat expansion at the fragile site as the cause of FXS led to the recognition of expansion of unstable nucleotide (microsatellite) repeats, notably trinucleotide repeats, as a previously unknown mutational mechanism underlying certain human diseases - now known to include more than 60 neurological and neuromuscular disorders. Although Steve expected that the CGG repeat expansion at the FMR1 locus was an exception in the human genome at that time, more recent work from multiple groups has shown that polymorphic CGG repeats are more prevalent in the human genome than we previously appreciated (being found at more than 6,000 loci). These CGG repeats could affect our genome at the DNA, RNA, and protein levels. Steve's work on CGG repeat instability and CGG repeat RNA toxicity will undoubtedly increase our understanding of these CGG repeats in the human genome.

Since the discovery of FMR1, Steve's lab has made major contributions to our understanding of the encoded Fragile X Mental Retardation Protein (FMRP), deficiency in which is the cause of FXS. The Warren lab discovered that FMRP was a selective RNA-binding protein and identified specific FMRP mRNA targets in the brain. The lab also identified the FMRP domains necessary for RNA binding and discovered that FMRP represses translation through its association with polyribosomes. Further studies dissected the underlying mechanisms of translational repression, including an association with the RNA-induced silencing complex (RISC), microRNAs and FMRP phosphorylation status. Analysis of FMRP missense mutations revealed that the loss of RNA binding and regulation of translation was the cause of FXS. Furthermore, the biology of FMRP was linked to the control of protein synthesis, which is important for learning and memory. A particularly impactful aspect of Steve's insight was his collaboration with Kim Huber and Mark Bear on the mGluR5 theory of FXS, which led to clinical trials of drugs that target the glutamate receptor mGluR5. Furthermore, through a novel fruit fly chemical screen based on a serendipitous observation, Steve's lab was the first to report that GABA receptor agonists could have therapeutic effect in FXS. These studies on FMRP function were paradigm-shifting, as they paved the way for the field to better understand the underlying basic science of RNA-binding proteins and to develop mechanism-based therapeutic strategies for neurodevelopmental disorders such as autism, providing an excellent example of 'bench to bedside' for brain disorders.

In recognition of these formative contributions to the field and for advancing our understanding of brain function and the resulting translational health ramifications, Steve received virtually all of the most prestigious accolades, including membership in the National Academy of Sciences, the National Academy of Medicine, and the American Academy of Arts and Sciences. He received the William Allan Award, the American Society of Human Genetics' highest honor. In addition, Steve was an inaugural inductee of the National Institute of Child Health and Human Development's Hall of Honor for the "identification of triplet 
repeat expansion as the cause of fragile $\mathrm{X}$ syndrome and as an entirely new inherited mechanism of genetic disease." In 2011, Steve received the March of Dimes/Colonel Harland Sanders Award for lifetime achievement.

Steve was not only a game-changer for science; he was also an inspirational mentor to us and so many others, always helping to develop the careers of his trainees and other colleagues while building the Emory and broader FX research communities. Steve was kind, honest, generous, humble, and thoughtful, which contributed to his inspirational role in our science and careers. Steve's critical insight, ideas, and encouragement were always valued. "Try this ... wouldn't that be very interesting ... it might be possible to do this ... take risks," he said. It would be difficult to comprehend how much positive impact Steve's wisdom and inspiration had on the individuals around him and far beyond.

Steve is survived by his wife, Dr. Karen Warren, whom he met at MSU more than 45 years ago; his son, Thomas Warren; and his son's fiancée, Desiree Chand. Steve's passing is an end of an era. He will be dearly missed by all of us at Emory, our fragile $\mathrm{X}$ research colleagues, his many friends and the entire scientific community.

Peng Jin (D) $1 \bowtie$ and Gary J. Bassell (DD) $2 \bowtie$

${ }^{1}$ Department of Human Genetics, Emory University School of Medicine, Atlanta, GA, USA. ${ }^{2}$ Department of Cell Biology, Emory University School of Medicine, Atlanta, GA, USA.

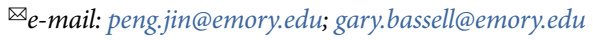

Published online: 13 September 2021 https://doi.org/10.1038/s41593-021-00922-5

Acknowledgements

We would like to thank David Nelson, Huda Zoghbi, Harry Orr and Thomas Glover for their comments. 